\title{
El cultivo del cacao venezolano a partir de Maruma*
}

\section{Luis Alberto Ramírez MéndeZ}

Profesor en la Maestría de Historia en la Escuela de Historia, Facultad de Humanidades y Educación de la Universidad de Los Andes (Venezuela). Correo electrónico: luisramirez811@gmail.com. El autor es Licenciado en Historia de la Universidad de Los Andes (Venezuela), Magíster Scientiae en Ciencias Políticas de la misma Universidad y Doctor en Historia en la Universidad Central de Venezuela (Venezuela). Miembro del Grupo de Investigación de Historia de las Regiones Americanas (GIHRA) de la Universidad de Los Andes (Venezuela). Entre sus publicaciones recientes tenemos: "Presencia y trascendencia de la revista virtual Procesos Históricos", en Anuario Colombiano de Historia Social y de la Cultura Vol. 40 Suplemento No. 1 (2013) y "Los maestros artesanos en Mérida, siglos XVI-XVII", en Presente y Pasado Año 18, No. 26 (julio-diciembre 2013). Hay que señalar entre sus temas de interés aquellos dedicados a la historia de las mentalidades y a la historia social y económica.

Recibido: 23 de mayo de 2014

Aprobado: 12 de agosto de 2014

Modificado: 11 de marzo de 2015

Artículo de investigación científica

DOI: http://dx.doi.org/10.15648/hc.27.2015.3

Este artículo forma parte del proyecto: "Evolución geo-histórica del sur del Lago de Maracaibo (siglos XV-XIX”, financiado por CDCHT. Universidad de Los Andes (Venezuela).

Esta publicación está bajo una licencia Creative Commons Reconocimiento-NoComercial 4.0 


\title{
El cultivo del cacao venezolano a partir de Maruma
}

\section{Resumen}

La presente investigación está centrada en la expansión del cultivo del cacao criollo o venezolano, a partir del hallazgo efectuado por los hispanos de las arboledas sembradas por indígenas en Maruma, al sur del Lago de Maracaibo. Principalmente, busca determinar la ruta de difusión del Teobroma en la planicie lacustre, la Gobernación de Venezuela y el Nororiente de la Nueva Granada, durante los siglos XVI al XVIII. Para ello, se basa en un análisis documental sobre la ubicación y difusión de los cacahuales, de acuerdo con la información que proporcionan las fuentes existentes en el Archivo General de Indias (AGI), Archivo General del Estado Mérida-Venezuela (AGEM) y la Biblioteca Nacional Febres Cordero (BNFC). El estudio se inscribe en la corriente de historia agraria y utiliza los métodos cuantitativos para el procesamiento de las fuentes.

Palabras clave: Plantas de cacao, sur del Lago de Maracaibo, análisis documental, historia agrícola.

\section{Venezuelan cocoa cultivation from Maruma}

\begin{abstract}
This research analyzes the expansion of Creole or Venezuelan cocoa cultivation from the discovery of indigenous plantations by Hispanics in Maruma, in the south of Lake Maracaibo. It also analyses their diffusion process towards the Government of Venezuela and the northeast of the Nueva Granada, from the sixteenth to the eighteenth centuries. The study is based on documentary analysis about the location and expansion of their crops according to the information provided by the existing sources in the Archivo General de Indias (AGI), General Archive of the State Merida (AGEM) and the Febres Cordero National Library (BNFC). In this study, quantitative methods are applied and the study meets the agrarian history mainstream.
\end{abstract}

Key words: Cocoa, south of Lake Maracaibo, groves crops, agrarian history.

\section{Cultivo de cacau venezuelano de Maruma}

70 Resumo

No presente inquérito, a expansão do cultivo ou Criollo venezuelano cacau proveniente de plantações achado indígena feitas por hispânicos no Maruma, ao sul do Lago Mara- 
caibo e do processo de difusão para o governo da Venezuela e do Nordeste obrigatório Nova Granada, durante os séculos XVI e XVIII. O estudo é baseado na análise documental sobre a localização e expansão de seus cultivos de acordo com a informação fornecida por fontes existentes no Archivo General de Indias (AGI), Arquivo Geral do Estado Mérida-Venezuela (AGEM) e Febres Cordero Nacional Biblioteca (FCNB). Em fontes de processamento têm vindo a utilizar métodos quantitativos e estudo faz parte da história agrária atual.

Palavras-chave: Cacau, sul do Lago Maracaibo, bosques, culturas, história agrária.

\section{La culture du cacao vénézuélien de Maruma}

\section{Résumé}

Cette recherche est centrée sur l'expansion de la culture du cacao créole ou vénézuélien, à partir de la trouvaille faite par des Hispaniques des arbres plantés par des indigènes à Maruma, au sud du lac de Maracaibo. Elle cherche notamment à déterminer la route de diffusion du théobroma dans la plaine lacustre, la Province («Gobernación») du Venezuela et le Nord-est de la Nouvelle-Grenade, entre le XVIè et le XVIIIè siècle. Elle se fonde sur une analyse documentaire des sources existant dans l'Archive Générale des Indes (AGI), l'Archive Générale de l'État Mérida, au Venezuela (AGEM) et dans la Bibliothèque Nationale Febres Cordero (BNFC). L'étude s’inscrit dans le courant de l'histoire agraire et se sert des méthodes quantitatives pour le traitement des sources.

Mots-clés: Cacaoyers, Sud du lac de Maracaibo, analyse documentaire, histoire agraire.

\section{INTRODUCCIÓN}

En cierta ocasión, Eduardo Arcila Farías manifestó su incertidumbre sobre la procedencia de los primigenios almácigos de cacao que se sembraron en Caracas y expresó algunas conjeturas sobre ese incierto origen, además consideró como el más conocido y admitido el que ha situado la cuna del Teobroma en Centroamérica y por tanto supone que las primeras semillas se hubiesen traído a Venezuela procedentes de Mesoamérica. Otro de sus cuestionamientos se centra en “...uno de los puntos que han permanecido hasta ahora más oscuros en la historia colonial venezolana es la época en 
que comenzaron los cultivos de cacao...". Al mismo tiempo que el historiador señala esas incógnitas, resalta la extraordinaria importancia sociocultural e histórica que reviste la expansión de las arboledas del Teobroma al afirmar que "venga de donde viniere" el notable desarrollo de su cultivo solo pudo alcanzarse mediante avanzados conocimientos sobre el suelo, agricultura y mercadeo para lograr un fruto destinado a la exportación. A diferencia del expresado autor, María Luisa Laviana Cueto enfatiza la importancia de las rutas culturales destacando la difusión universal del cacao como uno de los productos americanos con mayor influencia a nivel mundial, circunstancia reconocida por la UNESCO, al declarar el Teobroma como patrimonio de la humanidad ${ }^{2}$.

Ciertamente, la incógnita sobre el origen del cacao ha motivado algunas explicaciones, las cuales han generado más dudas que certezas. Por esa razón, esta investigación se propone ubicar geográficamente las arboledas de cacao venezolano o criollo durante el periodo prehispánico y la difusión de su cultivo hacia otras latitudes. Con ese propósito se acude a los resultados obtenidos en investigaciones botánicas realizadas sobre análisis mitocondriales que despejan los enigmas sobre la evolución de las especies de T. cacao. Luego se precisa la localización de los cultivos de cacao criollo realizados por los indígenas en el sur del Lago de Maracaibo, utilizando para ello la información que proporcionan las fuentes documentales existentes en el Archivo General de Indias (AGI), en el Archivo General del Estado Mérida-Venezuela (AGEM), en el Fondo Escribanías Españolas, particularmente en la serie Protocolos y Mortuorias, al igual que las resguardadas en la Biblioteca Nacional Febres Cordero (BNFC), en el Fondo Cabildo Mercedes de Tierras que contienen los títulos originales de la apropiación del suelo. Mediante esos testimonios se establece la ubicación de las arboledas de cacao, cultivadas por los naturales, las que fueron halladas por los españoles y la posterior propagación de sus semillas con el propósito de expandir los cultivos de ese delicioso fruto hacia otras áreas de la geografía venezolana y colombiana. El procesamiento de las fuentes se ha realizado utilizando los métodos cuantitativos y el estudio se inscribe en la corriente de historia agraria.

1 Eduardo Arcila Farías, Economía colonial de Venezuela (Caracas: Italgráfica, 1973, T. I), 141.

2 María Luisa Laviana Cueto, “Investigación e integración: La ruta del cacao en América Latina”, Tierra Firme Vol. XXV, No. 100 (2007): 485-499. 


\section{El Cultivo indígena del cacao criollo en Maruma}

Desde el punto de vista taxonómico existen diversas apreciaciones sobre la diversidad del cacao, siendo Morris, en 1822 quien por primera vez lo clasificó en dos grandes grupos: los criollos y los forasteros. En el presente siglo Henry Pittier (1930) ratificó esas dos tipologías y describió los criollos por presentar frutos alargados y puntiagudos, con cotiledones blancos; a diferencia del forastero cuyas nueces son redondeadas casi lisas y con cotiledones color violeta ${ }^{3}$. También establece que el Teobroma se halló en dos ubicaciones distintas: el criollo en Venezuela y el forastero en Nicaragua.

Las afirmaciones de Pittier fueron rebatidas por Chessman quien mantuvo la clasificación del Teobroma en criollos y forasteros y afirmó que ambos son pertenecientes a la misma especie, además sugiere que el criollo, -cuyas formas silvestres pueden ser encontradas desde Venezuela hasta el sur de México- sería originario de la cuenca superior del Amazonas, cuya diversificación se debió a la intervención del hombre 4 . Sin embargo, a la posición de Chessman se le ha opuesto la vulnerabilidad presente en los criollos a las enfermedades y plagas, por cuya razón se argumenta que sí descendieran de un mismo origen, ambas especies deberían presentar similar inmunidad contra los ataques de agentes bióticos, como solo la presentan los forasteros ${ }^{5}$.

De acuerdo con los resultados obtenidos en sucesivas investigaciones

3 Existen tres especies de cacao (sterculiáceas): una originaria de Nicaragua (Teobroma leiocarpa) que se trasladó a Trinidad, la cual se conoce como calabacillo; de allí se introdujo a Venezuela. La segunda, el cacao criollo o chuao (Theobroma cacao L Sp.), “...es un fruto alargado y fusiforme, más grueso y redondo en la base, verrugoso con cinco surcos hondos y cinco más intermedios alternantes y menos marcados por una sección blanco amarillenta o rosado pálido de sus semillas ovoideas y grandes, es el cacao por excelencia, el verdadero alimento de los dioses, teniendo todos sus elementos combinados en proporción ideal...”. Henry Pittier, Manual de las plantas usuales de Venezuela y su suplemento (Caracas: Fundación Eugenio Mendoza, 1971), 147-149.

4 Chessman, E.E., "Notes on nomeclatura, clasification and posible relationship of cacao populations", Trop. Agriculture (Trinidad) Vol. 21 No. 8, pp. 144-159. Falta año).

5 Motamayor, J. C. "Estudio de la variabilidad genética de los cacaoteros criollos de Venezuela Theobroma cacao L. mediante el uso de marcadores moleculares de tipo RFLP” (Tesis, Universidad Central de Venezuela, Maracay, Facultad Agronomía, 1995). 
efectuadas por Lanaud desde 1988, se pudo determinar la diferencia entre los cacaos criollos con respecto a los forasteros. Para lograr esas conclusiones se aplicaron las técnicas de análisis con marcadores bioquímicos y moleculares, cuyos indicadores establecieron las bases teóricas para sostener la evolución independiente tanto de unos y otros, determinar la ubicación geográfica de sus orígenes, los cuales se localizan a ambos lados de la barrera andina. Esto refuerza la hipótesis que los criollos no pudieron originarse a partir de los forasteros amazónicos ${ }^{6}$.

De esa forma, esos análisis tanto a nivel citoplasmático como mitocondrial del cacao sugieren que los criollos y los forasteros se diversificaron separadamente durante la evolución de las especies o partiendo de una especie común relacionada con T. cacao. Igualmente debe reconocerse a la hoya del alto Amazonas como un centro primario de diversidad de la subespecie sphaerocarpum, con una considerable variedad genética y con una gran resistencia a las plagas, enfermedades fungosas y virales ${ }^{7}$. De acuerdo con esas investigaciones se demuestra que las dos especies de cacao evolucionaron separadamente en dos espacios geográficos: uno ubicado en el alto Amazonas, y el otro en Venezuela, desde donde se expandió a Centroamérica y México (Véase Mapa 1).

6 C. Lanaud, "Nouvelles données sur la biologie du cacaoyer (Theobroma cacao L.): diversité des populations, système d'incompatibilité, haploïdes spontanés. Leurs conséquences pour l'amélioration génétique de cette espèce". Orsay: Université de Paris-Sud, 262 p. Thèse de doctorat -- Amélioration des plantes, 1989; C. Lanaud, Ph. Lachenaud, O. Sounigo, "Comportement en croisement des haploïdes doublés de cacaoyers (Theobroma cacao)", 1988. Canadian Journal of Botany, 66, 19861992; C. Lanaud, J.C. Motamayor \& O. Sounigo, "Le cacaoyer. In: Diversité génétique des plantes tropicales cultivées”, en P. Hamon et. al., Eds. Collection Repères, Cirad, 1999, 387; C. Lanaud, A. M. Riesterucci, J.A.K. Ngoran, D. Clement, M. H. Flament, V. Laurent \& M. Falque, A genetic linkage map of Theobroma cacao L. Theoretical and Applied Genetics 91(6-7), (1995), 987-993; V. Laurent, A. M. Riesterucci \& C. Lanaud, Variability for nuclear ribosomal genes within Theobroma cacao. Heredity 71: 1993a, 96-103; V. Laurent, A. M. Riesterucci \& C. Lanaud, Chloroplast and mitochondrial DNA diversity in Theobroma cacao. Theoretical and Applied Genetics 87 (1-2), 1993b, 81-88; V. Laurent, A. M. Riesterucci \& C. Lanaud, Genetic diversity in cocoa revealed by cDNA probes. Theoretical and Applied Genetics 88, 1994, 193-198.

747 María L. Sereno; Paulo S. B. Albuquerque; Roland Veconvsky; Antonio Figueira, "(Teobroma cacao L.) from Brazilian Amazon evaluated by microsatelitte markers". Conservacion genetics (2006) 7:1324. En http://worldcocoafoundation.org/wp-content/files_mf/sereno2006geneticdiversity312kb. pdf 


\section{Mapa 1}

Expansión de las especies de T. cacao criollo y forastero

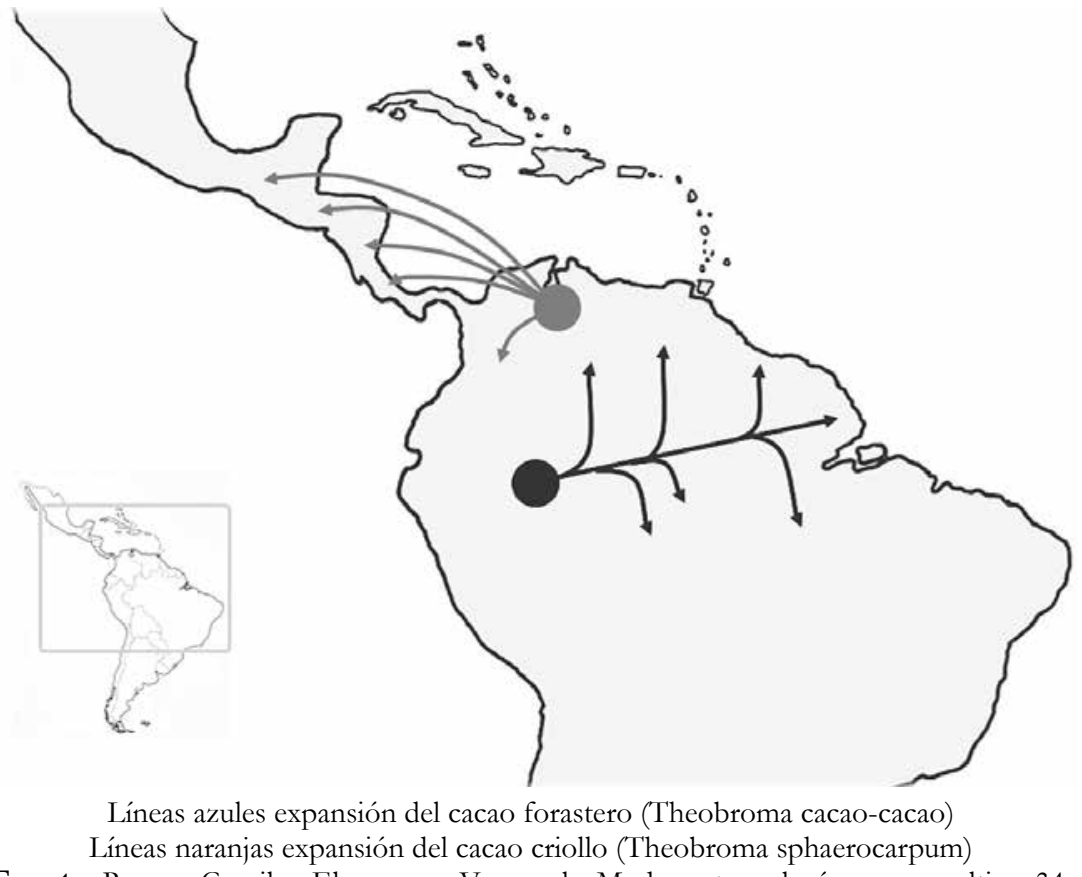

Fuente: Reyes y Capriles, El cacao en Venezuela. Moderna tecnología para su cultivo, 34.

Ahora bien ¿dónde está el espacio geográfico en el cual evolucionó el cacao criollo? La respuesta la ofrece primero Pittier $^{8}$, quien lo ubica al sur del Lago de Maracaibo. También lo afirma Arcila Farías y y finalmente lo confirman Reyes y Capriles.

Para determinar esa ubicación, Reyes y Capriles se basaron en dos argumentos: uno edáfico y otro de biodiversidad. El primero de los factores se debió a los cambios climáticos que se experimentaron en el lapso de 1,5 millones años durante los cuales se sucedieron ciclos fríos y calientes con periodos alternados de sequía y humedad. Durante esos inter-periodos, las selvas amazónicas quedaron reducidas a pequeñas islas rodeadas por una vegetación xerófila, cuyas contracciones podrían considerarse como un poderoso mecanismo de especiación, ya que en sus hábitats sobrevi-

8 “...el cacao criollo o chuao (Theobroma Cacao L Sp.) se cultivaba en Chuao y Maracaibo...” Henry Pittier, Manual de las plantas usuales de Venezuela y su suplemento, 148.

9 Eduardo Arcila Farías, Economía colonial de Venezuela, T. I., 141. 
vieron diversas especies vegetales como el Teobroma y animales que se han sobrevivido hasta la actualidad, circunscritos en áreas dotadas de la suficiente humedad para permitirles su supervivencia ${ }^{10}$. Esas circunstancias estuvieron presentes en las hoyas hidrográficas ubicadas en las riberas y desembocaduras de los grandes ríos, particularmente en el sur del Lago de Maracaibo cuyas condiciones contribuyeron a la evolución del cacao criollo.

En segundo término, Reyes y Capriles plantean que en la planicie lacustre, la especie de cacao criollo, manifestó una amplia diversidad en formas y colores representados por los porcelanas ${ }^{11}$, en sus colores blanco-verdosos, verdes oscuros, rosados y rojos en sus formas lisas, al igual que el cacao Pentágona y los criollos andinos de frutos rugosos oriundos de Zea, Estanques, Novilleros, Hernández, entre otros. Lo expuesto confirma una biodiversidad cacaotera única en el mundo, lo cual representa una de sus características más importantes. Por esta razón consideran al sur del Lago de Maracaibo el "nicho ecológico" que dio origen al cacao criollo".

Ahora bien, lo expuesto por Pittier, Arcila Farías, Reyes y Capriles también se asienta sobre evidencias históricas, circunscritas al periodo de contacto indo-europeo, debido a que el cacao era cultivado desde el periodo prehispánico por los indígenas en el sur del Lago de Maracaibo, quienes lo denominaban con los nombres de espití, chiré y tiboo ${ }^{13}$ y con este preparaban una bebida caliente ${ }^{14}$. Asimismo, los naturales molían y cocían el cacao

10 Humberto Reyes, y Lilian Capriles de Reyes, El cacao en Venezuela. Moderna tecnología para su cultivo, (Caracas: Chocolates del Rey, 2000), 30-34.

11 Porcelana es un tipo de cacao de extraordinaria calidad definido como: “... insólito, mágico, sutil y delicadísimo... conocida por expertos mundiales por su excepcional poder aromático, de mil flores de porcelana, sólo una se convertirá en mazorca y produce a su vez, 25 almendras de un blanco nacarado de pureza incomparable que dará origen a un chocolate sin amargo alguno. Actualmente se cultiva en el sur del Lago de Maracaibo, pero especialmente en la estación del Pedregal, en las inmediaciones de El Vigía, donde se hallaron arbustos silvestres, sin contaminación con otras especies de cacaos para la compañía francesa Varlhona ubicada en Tain Hermitage". http://www.analitica.com/ va/arte/actualidad/8209705.asp Porcelana del Pedregal.

7612 Humberto Reyes, y Lilian Capriles de Reyes, El cacao en Venezuela. Moderna tecnología para su cultivo, 30-34.

13 Gonzalo Picón Febres, Libro Raro (Mérida: Talleres Gráficos Universitarios, 1964), 70-71.

14 Gonzalo Picón Febres, Libro Raro, 70-71. 
para obtener una cera, muy blanca que ofrecían a sus divinidades por ser su producto más apreciado en braserillos a los cuales llamaban chorote ${ }^{15}$.

A la llegada de los europeos, estos observaron y escribieron relatos sobre el cacao. En ese sentido, la noticia más antigua, hasta ahora conocida, la ofrece el mercader Galeotto Cey, quien recorrió parte del occidente de Venezuela entre 1549 y 1554. El comerciante describió cómo crecían silvestres los árboles de cacao, apreciando su corteza sutil, pulida y con pocas ramas, de cuyo tronco salían vainas las que contenían unos granillos similares a los garbanzos, los cuales tenían un sabor amargo. Además, agregaba que en Temistlán era muy abundante, pero muy escaso donde él había estado ${ }^{16}$.

Del mismo modo, el cronista cosmógrafo Juan López de Velazco afirmaba que el cacao era un fruto común en Mérida, pues en 1571 ya los peninsulares habían hallado en la ciudad de las nieves eternas, “...todo género de comida y cacao como el de la Nueva España..."17. Igualmente, Rodrigo de Argüelles y Gaspar de Párraga describieron en 1579, los rubros exportados desde la ciudad de las cinco águilas blancas entre los cuales incluyeron “...harinas, bizcochos, jamones, y tocinos y mucha ropa de algodón, y corambre y azúcares y cacao...."18.

Pero ninguno de los mencionados cronistas precisa el paraje donde se cultivaba el cacao. Por ello, surge esta interrogante: ¿cuál es la ubicación geográfica donde se hallaron los cultivos de cacao en el sur del Lago de Maracaibo?, Para responder a esa incógnita es muy valioso el testimonio

15 Pedro Simón (fray), Noticias historiales de Venezuela (Caracas: Academia Nacional de la Historia, 1963, T. II), 222.

16 Galeotto Cey, Viaje y descripción de las Indias (Estudio preliminar, notas e índices de José Rafael Lovera) (Caracas: Fundación Banco Venezolano de Crédito, 1995), 133-134.

17 "Corografía de la Gobernación de Venezuela y Nueva Andalucía, 1571-1574, por Juan López de Velazco", en: Relaciones Geográficas de Venezuela (Caracas: Recopilación, estudio preliminar y notas de Antonio Arellano Moreno. Academia Nacional de la Historia, 1964), 108.

18 "Descripción de la ciudad de la Nueva Zamora, su término y Laguna de Maracaibo, hecha por Rodrigo de Argüelles y Gaspar de Párraga de orden del Gobernador don Juan de Pimentel”, en Relaciones Geográficas de Venezuela (Caracas: Recopilación, estudio preliminar y notas de Antonio Arellano Moreno. Academia Nacional de la Historia, 1964), 207. 
ofrecido por Luis de Trejo ${ }^{19}$, quien anotó entre sus méritos el “... aver yo descubierto el ancón de Maruma, donde ay interesado su magestad más de zien mil árboles de cacao..."20.

Aunque la relación de méritos de Luis de Trejo está fechada en 1614, ese "descubrimiento" debió ocurrir hacia finales del siglo XVI y estos cultivos fueron plantados por los aborígenes, ya que se afirma que "...hera de los naturales que allí avitaban..."21 y esos cultivos eran custodiados por los belicosos Kirikires, por lo cual se debió acudir a escoltas armados para acceder al mismo ${ }^{22}$. Esa noticia también fue referida por Pedro Simón, quien en 1610 se hallaba en Mérida y manifestó que en “... la parte del Sur, está el ancón de Maruma, en cuyo paraje se halló una gran montaña de árboles de cacao..." 23 .

Ahora bien, debido a que este topónimo está totalmente desaparecido de la geografía venezolana, otra pregunta que salta de inmediato es: ¿dónde está Maruma? El primer indicio sobre la ubicación de Maruma lo expone el teniente de corregidor de Mérida, Diego Prieto Dávila, juez reedificador de Gibraltar en 1600, quien ubica “...el Ancón de Maruma en jurisdicción de la provincia, tres leguas, poco más o menos término y jurisdicción de la villa de San Antonio de Gibraltar..." ${ }^{24}$.

Otras referencias sobre la situación de Maruma están insertas en el testi-

19 Luis de Trejo, hijo y heredero de Miguel de Trejo, quien recibió extensas tierras en la Sabana del Espíritu Santo, cercanas a Maruma, como refiere en su testamento al afirmar que poseía en el “... balle del Torondoy, una estancia de pan con más el monte de Mucufá y las tierras de Mocoguas de la otra banda del río Torondoy, donde oy tengo unas bacas, con más todas las savanas que están de una banda y otra del río..." "Testamento del capitán Miguel de Trejo. Mérida, [sin fecha] 1642”, AGEM, Protocolos T. XVII. ff. 239r-245v.

20 "Probanza de méritos de Miguel de Trejo y Luis de Trejo. Petición de Luis de Trejo", Mérida, 18 de junio de 1614, AGI, Patronato, 168, N 1, R. 1, ff. 6v-7r.

21 "Comunicación del Consejo de Indias". San Lorenzo, 5 de agosto de 1612, AGI. Santo Domingo, L. 860 f. 152r-v.

22 “...por estar de guerra los indios quiriquires cercanos a esta montaña..." "Carta de Bernabé de Oñate Mendizábal”, Moporo, 9 de noviembre de 1613, AGI, Quito, 28, N. 55. 2. ff.

23 Pedro Simón (fray), Noticias historiales de Venezuela, T. I, 105.

7824 "Apuntamientos y peticiones presentados por testigos sobre encomiendas de indios en la villa de San Antonio de Gibraltar, si deben continuar los encomenderos en sus encomiendas 1601. El capitán Diego Prieto Dávila recomienda se entreguen los indios del Ancón de Maruma a Gonzalo Palomino Rendón”, Mérida, 2 de febrero de 1600, BNFC, Ciudades de Venezuela, R. 9, Vol. 2, 287-288. 
monio rendido por Luis de Trejo, anteriormente citado y que dio origen a las indagaciones realizadas por la Corona. Por esa razón se emitió una real cédula dirigida a don Diego de Argote, gobernador y capitán general de Santa Marta y Río Hacha, para que notificara a la Corona sobre una montaña que contenía más de cien mil árboles de cacao, según se expresaba en una carta remitida por Juan de Benjumea Escalante en $1611^{25}$. Del mismo modo, también aparece en otra esquela suscrita por Bernabé de Oñate Mendizábal, quien maliciosamente afirmaba que algunos trujillanos, habían hallado una montaña de cacao ubicada a tres leguas del puerto de Barbacoas de Moporo, denominada Marumay, aclarando que su explotación fue sacada a subasta pública, para lo cual no se había presentado "ningún postor"26.

De acuerdo con esta última comunicación, los trujillanos desconocieron la jurisdicción de Mérida y por consiguiente la de la Real Audiencia de Santa Fe, lo cual ocasionó una discusión sobre los términos de ambas ciudades, los cuales habían sido delimitados en 1559, ese conflicto lo describe fray Pedro Simón al señalar que “... si bien hoy no está acabada de determinar cierta diferencia que se levantó los años pasados acerca de la jurisdicción por aquí de ambas audiencias sobre cierto bosque de cacao que se halló arrimado a la Laguna de Maracaibo, en el ancón de Maruma, si cae en términos comunes de las dos, o a cuál de ellas pertenezca" ${ }^{27}$. Finalmente, la ubicación exacta de Maruma la ofrece un documento fechado en 1691, relativo a los diezmos prediales de Gibraltar en donde se afirma que el “....ancón de Maruma en el cual sale la boca del río Buenavista, y por el cual arriba se dice Arapuey, y Quebrada del Alguacil..."28. De acuerdo con

25 "Real cédula dirigida al gobernador de Santa Marta y Río Hacha", San Lorenzo, 5 de agosto de 1612, AGI, Santo Domingo, Legajo 6, f. 152r-v.

26 “...Por junio de este año di cuenta a vuestra majestad de algunos particulares que tienen necesidad de remedio esta provincia y agora le daré lo que vuestra majestad manda por sur real cédula al gobernador don García Airón, el año pasado de [1]612, un vecino de la ciudad de Trujillo, manifestó ante la real audiencia de Santo Domingo, cierta montaña de cacao que llaman Maruma y que está tres leguas de esta Barbacoas de Moporro, todo laguna abajo..." "Carta de Bernabé de Oñate Mendizábal", Moporo, 9 de noviembre de 1613, AGI, Quito, 28, N. 55. 2. ff.

27 Pedro Simón (fray), Noticias historiales de Venezuela, T. I, 225.

28 "Testimonio de autos obrados por el bachiller Juan Feliz de Herrera, sacristán mayor que fue de la ciudad de San Antonio de Gibraltar y juez de diezmos en ella, y el Dr. D. Andrés Antonio de Montenegro, presbítero juez de diezmos actual de dicha ciudad en orden al diezmo de los Bobures que pretende la provincia de Maracaibo adjudicarse, perteneciendo a la dicha ciudad de Gibraltar como consta de estos autos según sus límites y linderos que van en 158 hojas numeradas. 1690”. Gibraltar, 10 de octubre de 1691, AGI. Escribanía 77,6B. Exp. 3. f. 9r-v. 
esa descripción Maruma debió extenderse desde el lindero entre Mérida y Trujillo es decir entre las márgenes del río Pocó, la ciénaga de Buena Vista hasta la quebrada del Alguacil precisamente en donde se encuentra actualmente La Dificultad (Municipio Sucre-Estado Zulia, véanse Mapas 2 y 3.

Al parecer esa disputa fue dirimida y resuelta, porque en 1626 el gobernador Juan Pacheco y Maldonado le asignó a Luis de Trejo, el "descubridor de Maruma” una estancia de ganado mayor situada “...de la otra banda del río de Arapuey, hazia la laguna de Maracaibo, después de medida y enterada la que vuestra merced tiene hecho merced a Juan de Paredes, tanto en ancho como en largo..." ${ }^{29}$. De aquellas tierras, Luis de Trejo y su esposa Isabel de Rojas transfirieron a Francisco Hernández, “...cuatro mil setecientos árboles de cacao, los cuales se han de contar y enterar en ellos al dicho Francisco Hernández, los más sercanos linde con otros mil árboles de cacao que en el dicho sitio de Arapuey le vendimos por escritura de venta del veinte y uno de octubre de mil seiscientos veinte y tres..." 30 .

Posteriormente, Trejo y su esposa, dotaron a una niña huérfana que criaron en su casa, llamada Isabel de Rojas, para que se casara con Gabriel Peña Cabrera “... con una estancia en Arapuey, casas que están en la jurisdicción de Mérida, junto a San Antonio de Gibraltar, con los árboles de cacao que allí hubiere, que serán seis estancias de pan..." ${ }^{31}$. Años después, doña Beatriz de Rojas, ya viuda de Luis Trejo, resolvió cederle otras extensiones, “... por averla criado en mi casa, por averme servido desde su niñez le hago donación de mil árboles de cacao, en la tierra que están sembrados todo lo cual es en el sitio que llaman de Arapuey, con otros mil que están en dicho sitio... sus linderos con estancia de los herederos de Juan de Paredes y con estancias y tierras de nuestra Señora de la Merced y con la quebrada de Arapuey..."32. En 1638, al testar, Luis de Trejo declaró como

29 "Merced a Luis de Trejo". Mérida, 6 de febrero de 1626. BNFC, Cabildo. Mercedes de Tierra. Caja 11. Doc. 1. f. 100r-v.

8030 "Carta de transacción y venta". Mérida, 28 de mayo de 1627, AGEM, Protocolos T. IX. ff. 348r-352v.

31 "Carta de dote de Isabel de Rojas". Mérida, 12 de marzo de 1636, AGEM, Protocolos T. XIII ff. 313r-315r.

32 “Carta de donación”. Mérida, 26 de abril de 1646, AGEM, Protocolos T. XIX. ff. 38v-39r. 
suya una estancia en Arapuey y una roza en la quebrada del Alguacil ${ }^{33}$.

Del mismo modo, Luis Trejo vendió a Francisco Hernández unas tierras en Arapuey. Sucesivamente, Hernández profesó como religioso en el convento de Nuestra Señora de la Merced en Cartagena de Indias y vendió a aquellos religiosos sus tierras de Arapuey ${ }^{34}$. En 1633, los mercedarios ampliaron su propiedad con otra donación que les otorgó Luis Trejo ${ }^{35}$. Igualmente, los monjes obtuvieron una merced del gobernador Fernández Valentín, por cuatro estancias, en 1638 y otra que le compraron a Brígida de Tolosa, situadas “...entre la dicha quebrada de Moyapá corriendo hacia el Alguacil y camino real que va de esta ciudad para Pocó y desde dicho camino corriendo hacia la laguna la dicha quebrada del Alguacil abajo hasta las juntas de ella con la de Muyapá..."36. Adicionalmente, el cabildo de Mérida concedió dos mercedes de tierra, una a Josep Rodríguez Melo y otra a Antonio de Orduña ambas refieren a Maruma y ubican las propiedades cedidas entre las riadas del Aguacil y el Arapuey, en 162637.

A pesar de la existencia del cacao en el sur del Lago de Maracaibo, durante las dos décadas inmediatas a la fundación de Mérida (1558), esas tierras cálidas y húmedas, solo fueron aprovechadas para el cultivo del maíz, la yuca y otras raíces, destinadas al consumo alimentario de los indígenas y

33 “Testamento de Luis Trejo". Mérida, 22 de junio de 1638, AGEM, Protocolos T. XVI. ff. 39r-46r.

34 "Carta de donación”. Mérida, 9 de marzo de 1633, AGEM, Protocolos T. XIII. f. 237r-v.

35 "Carta de donación”. Mérida, 9 de marzo de 1633, AGEM, Protocolos T. XIII. f. 237r-v.

36 "Visita de los oidores Modesto de Meller y Diego de Baños y Sotomayor. 1655-1657”. Composiciones. "Composición de Domingo Fernández". San Antonio de Gibraltar, 24 de marzo de 1657, AGI, Escribanía de Cámara. Legajo 836-c., f. 169v.

37 En 1626, Joseph Rodríguez Melo, ocurrió ante el gobernador Juan Pacheco y Maldonado para solicitar se le hiciera merced de dos estancias de pan había labrado ubicadas “...desde la puerta de la estancia de Manuel Barbuda hacia la Arenosa, el camino real es a la mano hasta el camino que va al trapiche de Tomás de Aranguren, que lo tengo labrado... hacia la laguna de Maracaibo, el ancón de Maruma dándole ancho y largo de la dicha estancia y arboleda de cacao hacia la laguna y por los lados linda con estancias de Juan Boscán y por la otra Andrés Gallardin..". "Solicitud de merced”, Mérida, 5 de enero de 1626, AGEM, Mortuorias T. IV, "Mortuoria de Joseph Rodríguez Melo", f. 203r-v. De la misma forma en 1626, Antonio de Orduña solicitó dos estancias de pan ubicadas “... en el camino que ba de la dicha ciudad de Xibraltar a Arapuey, pasando por un caño que llaman el Xaguei Berde, largo de ella arrimando al dicho caño Xaguei a una i otra mano del dicho camino y lo ancho del dicho caño hacia Arapuey y Maruma...”. "Merced otorgada por el capitán Juan Pacheco y Maldonado, gobernador de Mérida a Antonio de Orduña", Mérida, 31 de enero de 1626, BNFC, Cabildo Mercedes de Tierra, Caja 12, Documento 1, f. 95r-v. 
del algodón para la elaboración del hilo de pita y los lienzos. También fueron utilizadas para el tránsito de la producción agrícola y artesanal desde los valles altos hacia sus embarcaderos, desconociendo la extraordinaria potencialidad del cacao como producto de exportación. Por esa razón, el proceso productivo en aquella planicie, se inició posterior al de los valles altos inter-montanos. Esa situación, se debió fundamentalmente a que las actividades agrícolas desarrolladas por los peninsulares que se asentaron en Mérida, estuvieron determinadas por sus hábitos dietéticos, los que definieron los cultivos prioritarios especialmente de cereales privilegiados en la mesa de los europeos.

En ese sentido, es fundamental recordar que el menú de los españoles se basaba en el consumo del pan de trigo, las hortalizas y berzas, cuyas labranzas fueron exitosas en pisos altitudinales superiores a los $1.500 \mathrm{mts}$., donde el suelo, la humedad y el clima eran óptimos para esos vegetales, destinados a satisfacer al creciente mercado, tanto citadino como foráneo ${ }^{38}$, lo que estuvo en detrimento del inicial aprovechamiento de la planicie lacustre. Aquella percepción fue modificada debido a inesperados hechos ocurridos en la Nueva España, los que incentivaron el excepcional crecimiento de las haciendas cacaoteras en la planicie lacustre. Ello, se debió a que el cacao era consumido ${ }^{39}$ por las culturas indígenas prehispánicas, particularmente las de Mesoamérica ${ }^{40}$.

38 Luis Alberto Ramírez Méndez, "De la tentación al pecado de la comida del convento de Santa Clara de Mérida”, en Ensayos Históricos. Anuario del Instituto de Estudios Hispanoamericanos No. 20 (2008): 41-56.

39 C. Michel Riley, "El prototipo de la hacienda en el centro de México. Un caso en el siglo XVI", en Enrique Florescano (comp.), Haciendas, latifundios y plantaciones en América Latina (México: SIAP-CLAPSO, Siglo XXI Editores, 1979), 51.

40 "Un grupo de investigadores mexicanos acaba de dar a conocer un descubrimiento interesante en el que se han encontrado restos de cacao con 3.750 años de antigüedad en una vasija hallada en una excavación arqueológica en la ciudad de Veracruz. Este nuevo descubrimiento aumenta la datación de la utilización del cacao que se estableció el año pasado en unos 3.100 años. En el año 2007 los expertos descubrían que la bebida de cacao era más antigua de lo que hasta el momento se había estipulado, gracias a los restos arqueológicos de unos recipientes de cerámica hallados en el valle Ulua (Honduras), se databa la antigüedad del uso del cacao en unos 3.100 años. En los recipientes de cerámica se encontraron restos de teobromina, una sustancia alcaloide que sólo se encuentra en el cacao y principalmente en sus semillas". http://www.gastronomiaycia.com/2008/07/31/cacaocon-3750-anos-de-antiguedad/ "El chocolate, tal como ahora le usamos, no era conocido de los indios, lo que ellos tomaban venía á ser lo que hoy llamamos «cacao frío» ó «espuma de cacao,» y que aun se vende en los tianguis ó mercados de los pueblos. Mezclaban con el cacao varias yerbas, 
Pero en Nicaragua durante el siglo XVI, especialmente a partir de 1525, las plantaciones cacaoteras de Soconusco compuestas por arboledas de cacao se habían transformado en espacios agrícolas de baja productividad a punto de arruinarse, los cuales se mantuvieron a duras penas por la demanda de cacao de alta calidad entre las clases elevadas mejicanas. Los cacaotales, viejos y descuidados fueron especialmente sensibles a los efectos causados por los desastres naturales como los huracanes de 1612 y 1659, además, los cultivos fueron abandonados, al ser desplazados por las actividades ganaderas que eran más rentables que la cacaotera ${ }^{41}$.

Adicionalmente, la cohabitación de los invasores con los aborígenes propició el contagio y la transmisión de las temibles enfermedades procedentes del viejo mundo, contra las cuales los nativos carecían de inmunidad. La inmediata consecuencia de la contaminación con tan terribles enemigos biológicos fue la dramática disminución de la población amerindia ${ }^{42}$ las cuales entre otras actividades, cultivaba las tierras en México, determinando una substancial reducción en la producción alimentaria en aquel virreinato $^{43}$. Ambas causales ocasionaron la escasez del cacao y motivó el aumento sostenido de su precio durante las décadas finiseculares del XVI. Por esta razón, el ayuntamiento mejicano solicitó al virrey instituir “... una bolsa de cacao para estabilizar el mercado y combatir el acaparamiento de ese producto básico" 44 .

Durante aquellos años, los mercaderes estimulados por los altos precios

especias, chile, miel, agua rosada, granos del pochotl ó ceiba, y especialmente maíz. Conocían varios métodos para preparar la bebida; pero siempre en frío, y así se tomaba. Lo general era moler el cacao y demás semillas, desleír la pasta en agua, separar una parte y ponerla en mayor cantidad de agua, batir el líquido y pasarle varias veces de un vaso á otro, dejándole caer desde alto para que formase espuma. Los Mejicanos hacían una preparación del cacao en frío y en Nicaragua se preparaba una bebida de cacao cocida". Tulio Febres Cordero, "El chocolate y el chorote. Estudio histórico", en Archivo de Historia y Variedades, (Caracas: Parra León Hermanos, 1930. T. I), 65-66.

41 Manuel Miño Grijalva, El cacao Guayaquil en la Nueva España, 1774-1812 (Política imperial, mercado y consumo) (México: El Colegio de México, 2013), 82-83.

42 H. J. Stanley y H. Stein Bárbara, La herencia colonial de América Latina (México: Siglo XXI Editores, 1975), 40. Jonathan D. Israel, Razas, clases sociales y vida política en el México Colonial 1610-1670, (México: Fondo de Cultura Ecónomica, 1980), 22. Richard Konetzke, América Latina II. La época colonial (México: Siglo XXI, Editores, 1977), 95.

43 Woodrow Borah, New Spain century of depression (Berkeley, Los Angeles: 1951), 44.

44 Jonathan Israel, Razas, clases sociales y vida política en el México Colonial, 198. 
del cacao que les prometía elevadas ganancias, para de satisfacer la inusitada demanda de las nueces en Nueva España, iniciaron la búsqueda del fruto en otras latitudes. Esa situación coincidió con el hallazgo de bosques silvestres de $\mathrm{cacaO}^{45}$ en Maruma, en donde se inició su exportación. Al mismo tiempo, los peninsulares le agregaron al chorote leche, azúcar y especies, creando el chocolate a cuya bebida se aficionaron los ibéricos ${ }^{46}$.

La demanda comercial del cacao, aunado a las excepcionales condiciones edáficas que ofrecía la planicie del sur del Lago de Maracaibo cuyos sorprendentes vergeles rendían cacao de óptima calidad impulsó la creación de las haciendas. Simultáneamente, se estimuló el proceso de apropiación de la tierra, el desarrollo de las estancias y por ende de propagación de la especie. De ese modo, durante las décadas finales del siglo XVI, los emeritenses avanzaron rápida y decididamente en la colonización de los espacios favorables al cultivo del cacao, abriendo las labranzas en las zonas inmediatas a los acuíferos los cuales periódicamente eran inundadas por las corrientes fluviales que arrastraban abundante material orgánico desde sus torrenteras depositándolo en aquellas sabanas, tornando los suelos sumamente fértiles. Pero, al avanzar el proceso de roturación y la expansión de los sembradíos, quedó al descubierto una dura y frustrante realidad: las crecientes de los ríos, al tiempo que fertilizaban la tierra, también arruinaban las plantaciones con sus desbordamientos, perdiéndose con ello el esfuerzo empleado en los cultivos ${ }^{47}$.

45 Henri Pittier, Manual de las plantas usuales de Venezuela, 147-149.

46 Gonzalo Picón Febres, Libro Raro, 70-71.

47 Entre otros testimonios doña Francisca de Vergara expresaba que una estancia mercedada a su esposo Diego García de Carvajal “...se la llevó el río... Mojaján (San Pedro)...” "Composición de Doña Francisca de Vergara, viuda de Diego García de Carvajal”, San Antonio de Gibraltar, 26 de abril de 1657, AGI, Escribanía de Cámara, Legajo 836-c. Visita de los oidores Modesto de Meller y Diego de Baños y Sotomayor. 1655-1657, f. 82r-v. Los agustinos de Gibraltar declararon que las tierras que le habían sido asignadas en San Pedro y Arapuey eran “... inútiles de montañas y anegadizos y las de sabanas asimismo eriazas de poco o de ningún aprovechamiento..." "Composición de las tierras del Convento de San Agustín de San Antonio de Gibraltar", San Antonio de Gibraltar, 4 de abril de 1657, AGI, Escribanía de Cámara, Legajo 836-c. Visita de los oidores Modesto de Meller y Diego de Baños y Sotomayor. 1655-1657, ff. 171v-172r. Don Pedro de Silva declaraba que sus tierras en las márgenes del río Tucaní “...eran anegadizos por no haber tierra útil..." "Composición de Pedro de Silva”, San Antonio de Gibraltar, 4 de abril de 1657, AGI, Escribanía de Cámara, Legajo 836-c Visita de los oidores Modesto de Meller y Diego de Baños y Sotomayor. 1655-1657, f. 174r-v. Don Fernando de Valderrama, recibió tres estancias de pan en el valle del Espíritu Santo, contiguas al río Torondoy, pero sólo compuso dos porque la tercera se “...la anegó el río...” "Composición del capitán 
Ante ese difícil escenario se optó por abandonarlos calificándolos de desechados o anegadizos, inútiles e inservibles para la agricultura ${ }^{48}$ y desarrollar los cultivos sobre extensiones que estaban a salvo de las temibles riadas que devastaban las plantaciones. Ese escenario propició la existencia de zonas altamente codiciadas por sus inestimables condiciones ${ }^{49}$. En ese sentido, la incipiente tecnología determinó el carácter extensivo de las labores en relación directa con la propagación de la especie y sus elevados beneficios $^{50}$.

\section{LAS ARBOledas de CACAO}

Las primeras áreas de propagación del cultivo del cacao en el sur del Lago de Maracaibo se ubicaron adyacentes a la riada del Chirurí, en Maruma, donde los peninsulares hallaron los espléndidos cacahuales, que mostraban sus follajes y frutos con sorprendente exuberancia. Desde aquel espacio, las roturaciones fueron ensanchándose inmediatas a los cursos fluviales de los ríos La Arenosa o Piripí, Arapuey, Chirurí, las quebradas de las Guarichas o las Docellas (Caño Mico), Muyapá, la Tolosa, Chipansí o Tintinillo y Hacauay o el Alguacil, los valles de Castro, Mojaján o San Pedro,

Fernando Balderrama", San Antonio de Gibraltar, 5 de abril de 1657, AGI, Escribanía de Cámara, Legajo 836-c Visita de los oidores Modesto de Meller y Diego de Baños y Sotomayor. 1655-1657, ff. 178v-179r. Los padres del Convento de San Agustín declararon poseer una estancia en el valle del Espíritu Santo “... que por haberse anegado toda aquella parte de tierra con inundaciones del río Torondoy habrá quedado hasta media estancia de ganado mayor montuosa e inútil..." “Composición de tierra del Convento de San Agustín de Gibraltar”, Gibraltar, 4 de abril de 1657, AGI, Escribanía de Cámara, Legajo 836-c., Visita de los oidores Modesto de Meller y Diego de Baños y Sotomayor. 1655-1657, ff. 171v-172r.

48 En un testimonio de 1623, sobre la expansión de los cultivos en el valle de Mocotem, se afirmaba “...que son tierras que desde hace diez o doce años de beneficio se an perdido y secado los árboles de cacao y lo propio son las de San Antonio de Gibraltar y es dudosa su permanencia...". "Poder de Juan Pérez Cerrada para solicitar composición de tierras", Mérida, 23 de enero de 1623, AGEM, Protocolos T. VIII, ff. 13v-15v.

49 Esas zonas a salvo de las inundaciones se denominaron bancos y allí se cultivaba el cacao en óptimas condiciones. En la hacienda del capitán y sargento mayor don Juan Dávila y Rojas en Mojaján, se inventariaron en el banco de Santa Lucía y el pepeo, 11.000 árboles de cacao todos frutales, en el de Babures 5.100, en el de Santa Cruz 8.200 y el de San Isidro 8.600. "Inventarios de las estancias de Mojaján”, Mojaján, 29 de septiembre de 1667, AGEM, Mortuorias T. X. Mortuoria del capitán y sargento mayor Juan Dávila y Rojas, ff. 390r-391v.

50 Hermes Tovar Pinzón, Colombia. Imágenes de su diversidad (1492 a hoy) (Bogotá: Grupo Editorial Educar, 2007), 102. 
Mucutem, Tucaní. La propagación fue también vertiginosa en el valle del Chama, donde las plantaciones se difundieron sobre ambas márgenes de los ríos Onia, Chama, Curigría y Mocofoco o Mucujepe, los Caños Seco, y la quebrada Mocacay. Sucesivamente, fueron incorporados los valles de Mibambú, Capaz y Chimomó ${ }^{51}$ (Véase Mapa 2).

La formación de las arboledas de cacao fue gradual y paulatina, debido a que la siembra fue haciéndose en diferentes etapas. Las primeras roturaciones fueron consecutivas y se iniciaron con la deforestación de la selva tropical, especialmente de aquellos árboles gigantescos que poblaban las llanuras para ser sustituidas por los sotos de cacao.

Las primeras plantaciones fueron modestas; oscilaban entre menos de mil y tres mil pies de cacao, pero los propietarios preveían que podrían conformarse sembradíos que alcanzaban a más de diez mil y hasta quince mil árboles ${ }^{52}$. Ello determinó que en las haciendas existieran locaciones con árboles que eran de diferentes datas y edades. A esos espacios se les denominó "bancos o suertes" 53 y a cada uno se les designó con un nombre específico determinado por la cantidad de años que los árboles tenían sembrados, de acuerdo con su productividad, ya que se requerían entre

51 En 1623, Juan Pérez Cerrada, expresaba que “... por quanto en los llanos y bertientes de la laguna de Maracaibo... términos y jurisdicción de la ciudad de San Antonio de Gibraltar, a muchos años que tengo y poseo una estancia de ganado mayor en el sitio y comarca que llaman de Mocotem... abajo camino viejo que sale de ella para el puerto de San Antonio de la dicha laguna de Maracaybo, donde yo y Francisco de Belasco, Diego de Carvajal y Antonio de Santa Ana y Juan Muñoz bamos rozando y desmontando y poniendo algunos cacaos ... ". "Poder de Juan Pérez Cerrada para solicitar composición de tierras". Mérida, 23 de enero de 1623, AGEM, Protocolos T. VIII, ff. 13v-15v.

52 “...Item declaro por bienes míos los dichos quinientos árboles de cacao los quales están en tierras mías en el valle de la Savana del Espíritu Santo, términos de la ciudad de Xibraltar... de tierras para poder sembrar seis mil árboles de cacao..." "Testamento de doña Juana de Monsalve", Mérida, 13 de marzo de 1647, AGEM, Protocolos T. XIX, ff. 206r-208v. En 1638, don Fernando de Alarcón entregó como dote a su hija doña Petronila “... Iten más mil quinientos árboles de cacao de dos años en el mismo sitio de La Arenosa... más un pedazo de tierra pegados y contiguos a los dichos árboles de cacao y en dichas tierras de La Arenosa, en que se puedan sembrar hasta en cantidad de diez mil árboles de cacao..." "Carta de dote de doña Petronila de Alarcón”, Mérida, 16 de abril de 1638, AGEM, Protocolos T. XV, ff. 16v-18r.

8653 Doña Constanza Varela declaraba en 1645 que poseía en el valle de Chama “... una estancia en los llanos de los Guaroríes que tengo dos suertes de cacao la una de mil árboles y la otra de seiscientos...” “Testamento de doña Constanza Varela", Mérida, 8 de diciembre de 1645, AGEM, Protocolos T. XVIII, ff. 267v-271v. 
seis y ocho años de cultivo y cuidados para que las arboledas dieran su primera cosecha.

De esa forma, se separaban los labrantíos recién sembrados o menores de seis años ${ }^{54}$ que aún no habían fructificado, de aquellos que superaban esa edad y eran frutales ${ }^{55}$ y los que progresivamente eran mayores de diez años que se consideraban en máxima producción ${ }^{56}$, de los que se recolectaban frutos en dos, tres y hasta cuatro cosechas durante el año ${ }^{57}$. Finalmente, se hallaban los que por ser "... muy viejos ya no daban fruto".

De ese modo, los plantíos de cacao se sembraban en suertes de alrededor de mil árboles, que requerían aproximadamente de tres a cuatro hectáreas de extensión, porque los sembradíos no se hacían en hileras o dameros. Por el contrario, se atendían a los accidentes del suelo y se mantenían los árboles altos de amplias copas destinados a proporcionar sombra, los que requerían de mayor espacio para sus raíces.

Por otro lado, en aquellas zonas de elevada fertilidad, las plantaciones cre-

54 "Ítem cuatro mil árboles de cacao de edad de dos años, que están puestos y plantados en las tierras que llaman de la Arenosa y Arapuey, términos de esta ciudad en mil patacones..." "Carta de dote de doña María de Valecillos”, Mérida, 12 de abril de 1638, AGEM, Protocolos T. XV, ff. 10v-14r.

55 En 1638, el bachiller don Alonso de Cabrera y Roxas, hizo constar en el recibo de dote de su esposa doña Juana de Arismendi Montalvo "... tres mil árboles de cacao frutales de seis o siete años, los quales se apreciaron a cinco reales cada árbol importan mil ochocientos setenta y cinco pesos de plata..." "Recibo de la dote de doña Juana de Arismendi", Mérida, 20 de junio de 1639, AGEM, Protocolos T. XV, ff. $264 \mathrm{v}-269 \mathrm{v}$.

56 En 1627, en un testimonio del vicario de Mérida Francisco Yzarra de la Peña afirmaba “.... que por las experiencias que hay en esta tierra el árbol de cacao mientras más viejo da más fruto y aunque hay algunos de más de sesenta años siempre están buenos y fructíferos..." "Expediente para que se funde un convento de monjas en Mérida. Testimonio de Francisco Yzarra de la Peña", Mérida, 30 de marzo de 1627, AGI, Santa Fe, Legajo 133, f. 44v.

57 Entre otros ejemplos, en la hacienda de Isabel Durán, ubicada en la Sabana del Espíritu Santo de San Antonio de Gibraltar, se inventariaron en 1649 “... siete mil trescientos árboles de cacao frutales ... Ítem mas se contaron dos mil árboles de cacao nuevos de edad de dos años poco más o menos..." "Inventario de la hacienda del Espíritu Santo. Valle de la Sabana del Espíritu Santo", San Antonio de Gibraltar, 23 de junio de 1649, AGEM, Mortuorias T. IV, Mortuoria de Isabel Duran, f. 348r-v. Entre los bienes de Antonio Arias Maldonado en el valle de Bobures se hizo constar que habían “... dos mil árboles de cacao frutales de ocho años poco más o menos según parece Item más setecientos cincuenta y cuatro árboles de cacao de seis años poco más o menos. Iten más mil árboles de cacao frutales de edad de cuatro años poco más o menos. Ítem más dos mil trescientos árboles de cacao de dos años poco más o menos..." Mortuoria de Antonio Arias Maldonado. Declaración de bienes. El Valle de Bobures, 11 de noviembre de 1658. AGEM, Mortuorias T. VI, f. 183r. 
cían con mayor rapidez dando como resultado árboles de cacao con espléndidos ramajes que requerían de mayores superficies. Ello hacía que los arbustos se plantasen con una extensión intermedia, entre cada uno, de catorce $^{58}$ a diez y ocho ${ }^{59}$ pies, equivalentes aproximadamente entre 5,46 y 7,20 metros. Después de cumplido el ciclo de reproducción mediante los almácigos, se trasplantaban a las suertes o bancos en los cuales se plantaban hasta mil árboles.

Las cifras demuestran la creciente expansión del cultivo de cacao en la zona sur del lago durante la primera mitad del siglo XVII. En general, durante la primera mitad del siglo XVII, se reseñaban diez y siete suertes pequeñas comprensivas de menos de mil árboles frutales, otras trece que contenían de mil a dos mil. Sucesivamente, se refieren doce terrazgos que comprendían de tres mil a cuatro mil; otras cinco suertes en las que estaban plantados de cuatro mil a cinco mil; otras nueve haciendas que tenían sembrados entre cinco y diez mil, y finalmente cinco unidades de producción que contaban con más de diez mil árboles de cacao (Véase Tabla 1).

En la expansión de la frontera agrícola no se escatimaron recursos; por el contrario durante ese periodo las rozas y roturaciones incrementaron progresivamente para expandir las superficies cultivadas. Ello es apreciable al conocer el número de los bancos que tenían plantados árboles de cacao no frutales, es decir con edades menores a los seis años. Específicamente en el valle de Chama, se reseñó una parcela que tenía de dos mil a tres mil árboles. Entre tanto, al otro hito, en el valle del Espíritu Santo se registraron cuatro suertes con mil árboles; otros dos tablones de mil a dos mil; mientras en La Arenosa, se anotaba un banco de dos mil a tres mil y una suerte de cuatro mil a cinco mil. En el valle de Capaz, se registraron cinco suertes con menos de mil árboles y otra con más de dos mil a tres mil. También, se reseñaron bancos sembrados en los valles de Chirurí, Castro y Arapuey (Vease Tabla 1).

58 En 1639, Francisco de Castro vendió al padre Pedro de Miranda una estancia con seiscientos árboles de cacao, haciendo constar que "... se comprende en ellos divididos cada un árbol del otro catorce

pies..." "Carta de venta”, Mérida, 18 de marzo de 1639, AGEM, Protocolos T, XV, ff. 199v-201v.
59 En 1627, Miguel de Trejo vendió al padre Pedro Marín Cerrada una estancia con cuatro mil árboles por " ... la orden que en aquella tierra se siembra que es a diez y ocho pies de lo que un árbol y otro de cacao..." "Carta de venta", Mérida, 8 de marzo de 1627, AGEM, Protocolos T. X, ff. 171r-172v. 


\section{Tabla 1}

Cantidad de árboles de cacao frutales y no frutales en bancos o suertes en el sur del Lago de Maracaibo 1600-1650

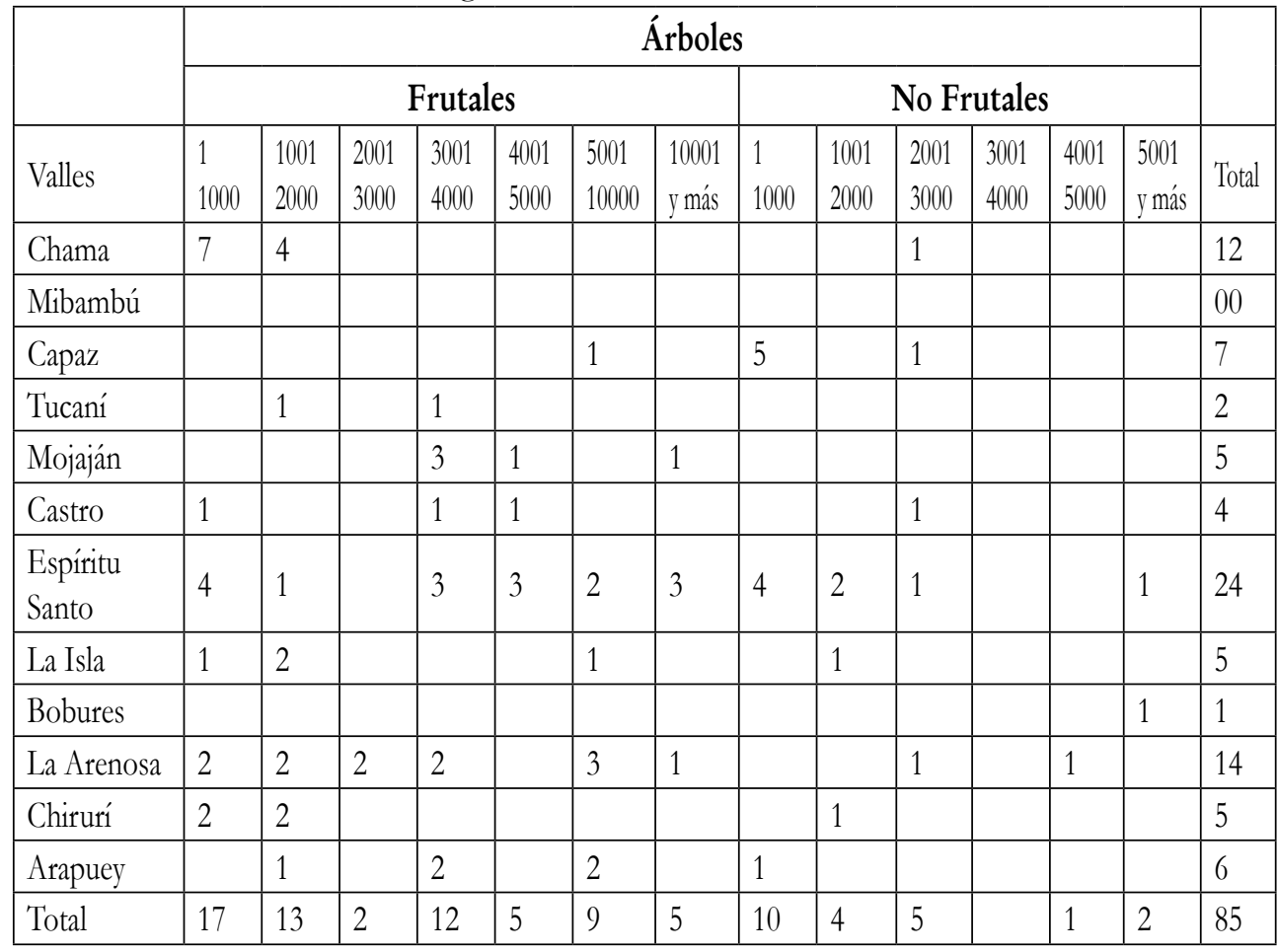

Fuente: Protocolos T. I-XL Mortuorias T. I-X, AGEM

Visita de los Oidores Modesto de Meller y Diego de Baños y Sotomayor. 1655-1657,

Composiciones, AGI, Escribanía de Cámara, Legajo 836-c.

En la segunda mitad del siglo XVII, es apreciable la expansión de los cultivos emprendida durante la primera mitad de aquella centuria. Para entonces, ya se reseñaban haciendas con mayor cantidad de árboles frutales, manteniéndose la tendencia en los hitos iniciales ubicados en los valles de Chama y Espíritu Santo; pero ya en los otros valles hay cifras significativas con suertes de árboles frutales (Véase Mapa 2).

En el caso del valle del Espíritu Santo, se localizaban cuatro haciendas con menos de mil árboles de cacao; dos tablones con más de dos mil; una suerte con más de tres mil; tres tablones con más de cuatro mil; siete comprendidas entre cinco a diez mil y otras tres haciendas con más de treinta mil. Entre estas se incluían las propiedades del Convento de Santa Clara de Mérida que para 1690, contaban con más de treinta mil árboles y las de 
los jesuitas que en su hacienda de La Sabana contenían 51.000 árboles de cacao y en La Arenosa tenían plantados más de 16.000 en $1684^{60}$ (Véase Tabla 2).

\section{Mapa 2}

Expansión de los cultivos de cacao criollo en el sur del Lago de Maracaibo a partir de Maruma (siglo XVII)

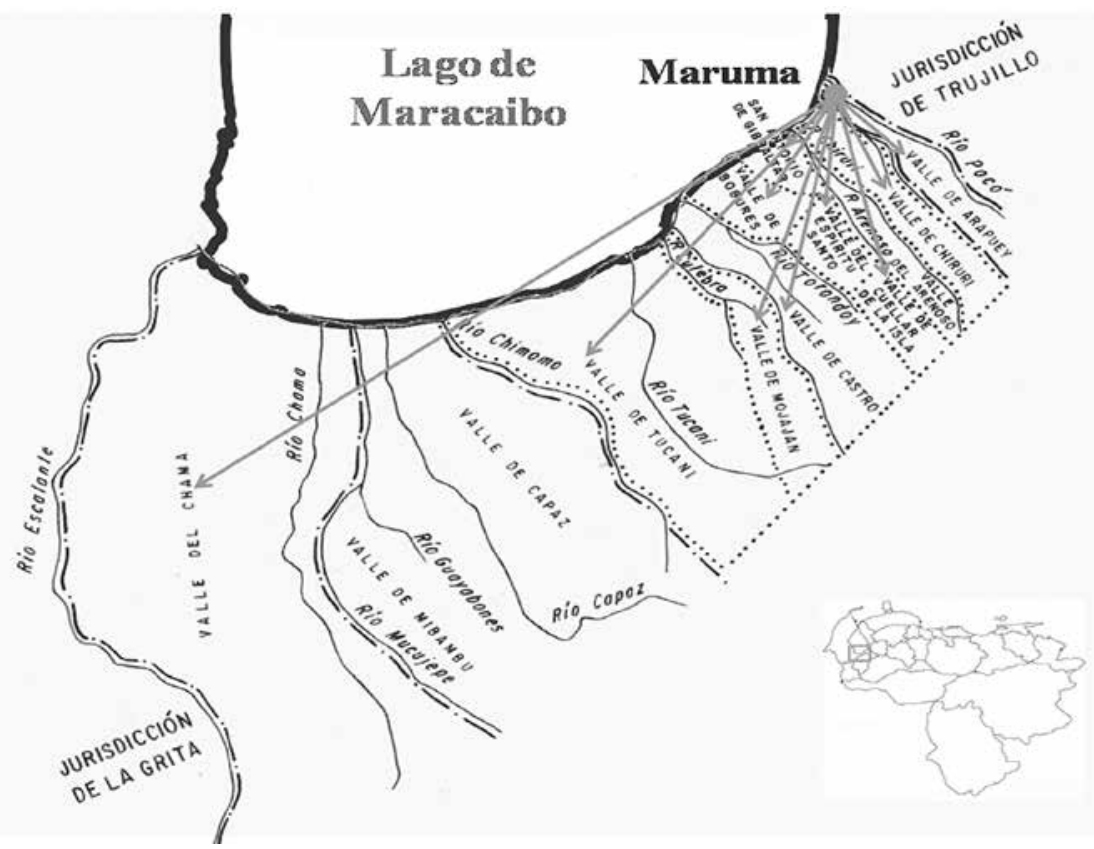

Fuente: AGEM. Protocolos T. I-XL Mortuorias T. I-X.

Visita de los Oidores Modesto de Meller y Diego de Baños y Sotomayor. 1655-1657, Composiciones, AGI. Escribanía de Cámara, Legajo 836-c.

En el otro extremo, el valle del Chama, se cultivaban dos parcelas con menos de mil árboles; cinco suertes que contabilizaban de mil a dos mil; cuatro parcelas que reseñaban de dos mil a tres mil; tres tablones que tenían de cinco mil a diez mil y dos haciendas comprensivas entre más de diez mil a veinte mil frutales. En tercer lugar, se hallaba La Arenosa, donde habían plantados cinco suertes de tres mil a cuatro mil; una parcela de cuatro mil a cinco mil; otro predio de cinco mil hasta diez mil y otro con más de diez mil (Véase Tabla 2 y Mapa 2).

60 Edda O. Samudio A., Las haciendas del colegio San Francisco Xavier de la Compañía de Jesús en Mérida. 1628-1767 (Caracas: Universidad de Los Andes, Arte, 1985), 368. 
Luego en el valle de Mojaján, donde se contabilizaba una suerte de mil a dos mil árboles; dos con cinco mil a diez mil; una comprendida entre diez mil a veinte mil y una con más de veinte mil árboles frutales. En los valles de Chirurí y Arapuey, se reconocían dos propiedades que contaban entre cinco a diez mil árboles y finalmente Mibambú que tenía una suerte con menos de mil; una con dos mil a tres mil y una con cuatro mil a cinco mil, siendo este el último espacio que se aprovechaba para labrar el fruto (Véase Tabla 2 y Mapa 2).

Por el contrario, la disminución de los plantíos de nuevos árboles o no frutales es evidente durante la segunda mitad de la misma centuria. Indudablemente esa circunstancia fue consecuencia de las nefastas dificultades experimentadas durante aquel periodo. Ello se puede apreciar al comparar la cifra de árboles no frutales anterior a 1650, que indicaba diecisiete plantíos menores de mil árboles y posterior a aquella fecha que solo se refieren dos. A pesar de que en Mojaján y La Arenosa se hallaban plantíos con más diez mil árboles de cacao nuevos, en el primer caso es el resultado del aprovechamiento de tierras a salvo de las terribles inundaciones, y en el segundo fue producto de la inventiva y destreza de los jesuitas en la expansión de sus haciendas. Ello también es apreciable por la ausencia de registros que reseñen árboles no frutales en los valles de Mibambú, Capaz, Tucaní y Cuéllar de la Isla, lo cual probablemente fue causado por los terribles eventos suscitados en los setentas de aquella centuria, la carencia de capital y la disminución de la mano de obra.

En total durante este periodo había ciento una haciendas que dividían sus plantíos de la siguiente forma: nueve con menos de mil árboles; quince con mil a dos mil; diez y siete con dos mil a tres mil; nueve de tres mil a cuatro mil; seis de cuatro mil a cinco mil; quince entre cinco mil a diez mil y diez y siete superaban la cifra de más de diez mil árboles frutales. Entre tanto, habían disminuido substancialmente las suertes de árboles no frutales, solo se reseñaron dos con menos de mil; cuatro con mil a dos mil; una con dos mil a tres mil; dos con tres mil a cuatro mil; tres con diez mil a veinte mil y una con más de veinte mil (Véase Tabla 2). 


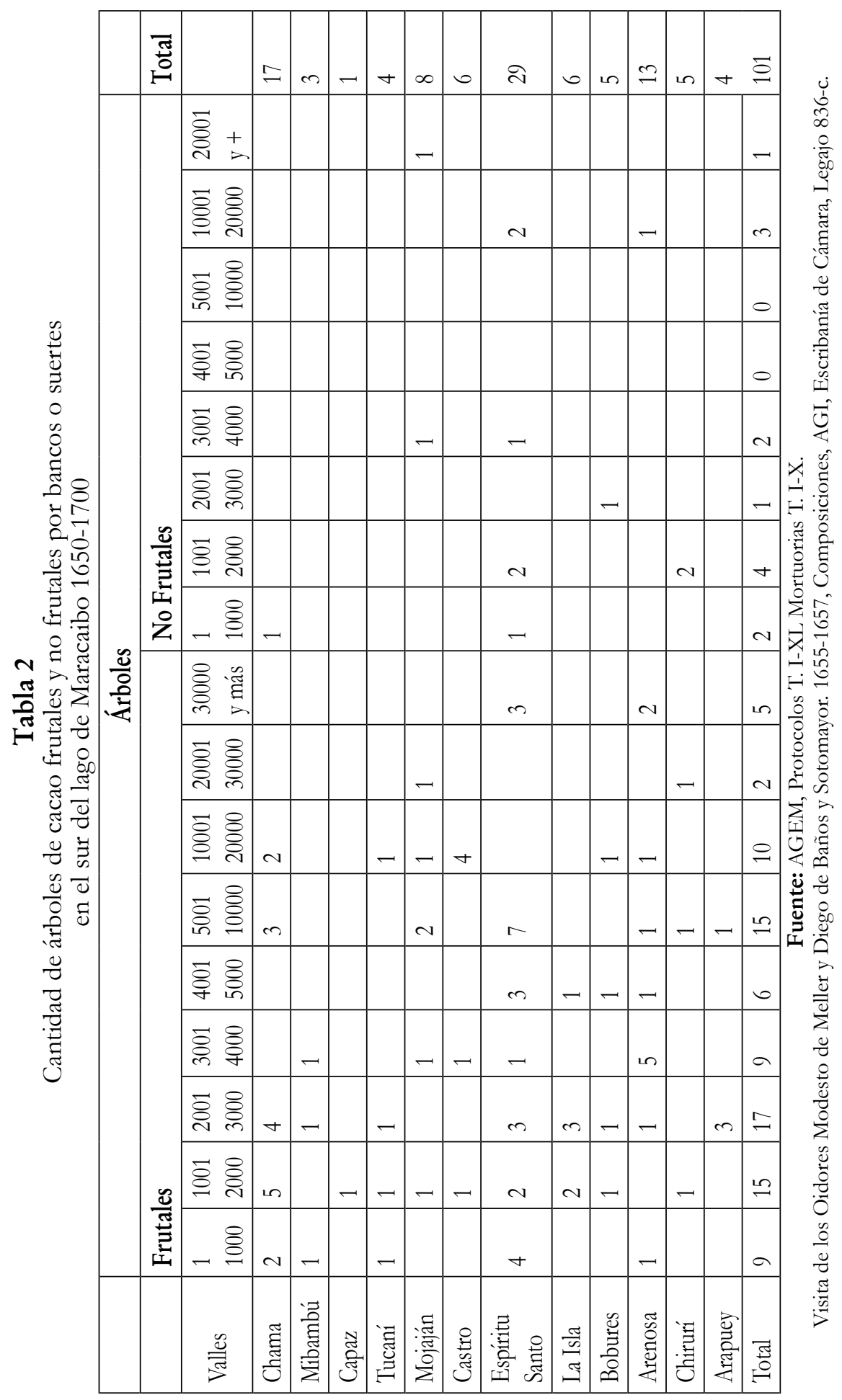


De acuerdo con los datos expuestos, se puede manifestar que la mayoría de las haciendas comprendían plantaciones de dos mil a tres mil árboles frutales; pero que también hubo una elevada incidencia en aquellas que contenían más de mil árboles de cacao, lo cual era resultado de nuevas roturaciones. Durante la etapa estudiada, los valles más extensamente cultivados fueron Espíritu Santo, La Arenosa, Chirurí y Arapuey debido a sus óptimas condiciones en la producción, al igual que su privilegiada ubicación, inmediatos al puerto de San Antonio de Gibraltar. Entre tanto, Mibambú y Capaz fueron menos aprovechados, debido a la distancia que los separaba del puerto y particularmente el primero, porque comprendía las tierras de resguardo.

En el sur del Lago de Maracaibo, durante los siglos XVI y XVII, la propagación del cultivo de cacao y la expansión de la frontera agrícola dieron como resultado que aproximadamente 644 propietarios, poseían 163.157 hectáreas de tierras, en las cuales habían cultivado 521.671 árboles de cacao, que producían 260,3 toneladas anuales del fruto, el cual mayoritariamente se destinaba al mercado mejicano ${ }^{61}$.

\section{LA EXPANSIÓN DEL CACAO CRIOLLO}

Ciertamente en la provincia de Caracas, a la llegada de los españoles no existía el cacao, como se prueba mediante la Relación de Juan Pimentel, quien no lo menciona entre las especies vegetales que se observaban en el valle del Ávila ${ }^{62}$, lo cual hace descartar que en esa zona y sus alrededores se cultivasen arboledas de cacao ${ }^{63}$. Pero la creciente demanda del cacao incentivó la introducción de su cultivo y como afirma Arcila Farías, si los hispanos encontraron abundancia de cacao en Mérida, “....resulta lógico pensar que de allí lo tomaron para llevarlo a otras regiones vecinas hasta llegar a extenderlo por toda la gobernación de Venezuela" ${ }^{64}$.

61 Luis Alberto Ramírez Méndez, La tierra prometida del sur del lago de Maracaibo y la villa y puerto de San Antonio de Gibraltar (siglos XVI-XVII) (Caracas: El Perro y la Rana, 2011, T. II), 187.

62 "Descripción de Santiago de León, Gobernación de Venezuela, 1578 por Juan de Pimentel", en Relaciones Geográficas de Venezuela (Caracas: Recopilación, estudio preliminar y notas de Antonio Arellano Moreno, Academia Nacional de la Historia, 1964), 111-140.

63 Eduardo Arcila Farías, Economía colonial de Venezuela, T. I., 141.

64 Eduardo Arcila Farías, Economía colonial de Venezuela..., T. I., 141. 
La difusión del cacao debió ocurrir a finales del siglo XVI o primeros años del XVII, porque el delicioso fruto ya había sido llevado y cultivado en los valles centrales de la provincia de Caracas, como se refiere en la relación geográfica de Diego de Villanueva y Gibaja, fechada en 1607, quien afirma que en la población de San Sebastián de los Reyes, distante como cuarenta leguas de Caracas hay “...algún cacao que se coje..."65. Pero esa realidad sería modificada rápidamente porque ocho años después en 1615, se notificaba de la difusión del fruto, como lo atestigua Hernán Gómez Román en su testamento quien declaró “... haber dejados plantados cuatro mil pies de árboles de cacao entre la quebrada de Curía e Ipaya... ${ }^{66}$.

Esa referencia sobre la fecha del inicio de los cultivos de cacao en la provincia de Caracas es ratificada por Antonio Vázquez de Espinosa, quien en 1629, describió el proceso de siembra de las arboledas, al relatar que en las estribaciones inmediatas a Caracas, entre el piedemonte y el litoral de la cordillera de la Costa, en un espacio que se dilataba en más de cuarenta leguas “... se han sembrado desde el año de 1615, grandes guertas y árboles de cacaguales en las cuales se da y se coge el cacao en grande abundancia..." ${ }^{67}$.

Del mismo modo, el relator también precisaba el origen de las semillas, al explicar que el cacao se había traído desde “... las sierras y montañas de tierra adentro, donde habían grandes montes y arboledas de cacao silvestre, donde se criaban, subían y se descollaban sobre los demás arboles, buscando el sol. De ellos se hicieron grandes almácigos de que plantaron y pusieron las guertas de estas arboledas y frutales" 68 . En la siguiente década, a partir de 1620, se registra el cultivo del cacao en el litoral central especialmente en Cuyagua, Choroní, Turiamo, Patanemo, Mamo, Caraballeda, Ocumare y al legendario Chuao ${ }^{69}$ (Véase Mapa 3).

65 "Relación Geográfica firmada por Diego de Villanueva y Gibaja en que se describe la Gobernación de Venezuela y provincia de Caracas, corregimientos de La Grita y Tunja y la Gobernación de los Mussos”, en Relaciones geográficas de Venezuela (Caracas: Recopilación, estudio preliminar y notas de Antonio Arellano Moreno, Academia Nacional de la Historia, 1964), 289.

66 Lucas Guillermo Castillo Lara, San Sebastián de los Reyes. La ciudad trashumante, 185.

67 Antonio Vázquez de Espinoza, Compendio y descripción de las Indias Occidentales, Separata de la

Revista Nacional de Cultura No. 68 (mayo-junio 1948): 32

68 Antonio Vázquez de Espinoza, Compendio y descripción de las Indias Occidentales, 32.

69 Juan Ganteaume, Chuao antes de la obra pía (Caracas: Editorial El Perro y la Rana, 2006), 70-71. Eduardo Arcila Farías, Economía colonial de Venezuela, T. I, 143-144. 


\section{Mapa 3}

Expansión de los cultivos de cacao criollo en Venezuela y la Nueva Granada (siglos XVI-XVIII)

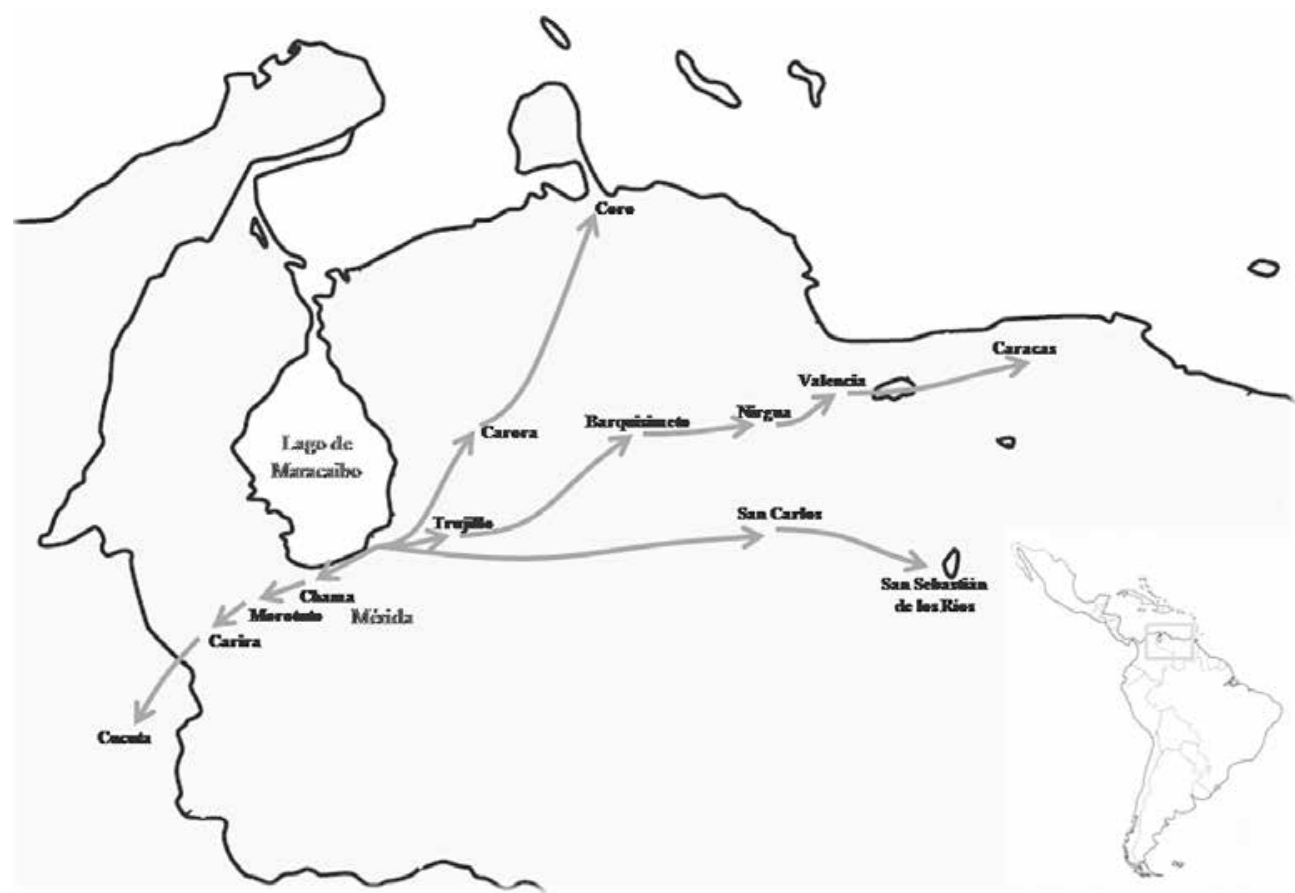

Fuente: Pedro José de Olavarriaga, Instrucción General y particular del estado presente de la provincia de Venezuela en los años de 1720 y 1721 (Caracas: Academia Nacional de la Historia, 1965), 289.

La expansión de la frontera agrícola en la provincia de Caracas fue de tal magnitud que en los siguientes 60 años el cacao se difundió hacia todas las jurisdicciones de la gobernación, especialmente en la capital, debido a las excepcionales condiciones que ofrecía el litoral Caribe. Las arboledas de cacao fueron contabilizadas por Olavarriaga en 1721, quien en la jurisdicción de Caracas, totalizó la cantidad de 1.679.900 árboles; en segundo lugar se hallaba la de Valencia, en cuyo espacio se registraron 1.272.900 árboles, en total se registraron en toda la provincia $4.546 .564^{70}$ árboles, lo cual explica los crecientes ingresos de los propietarios de las haciendas, lo cual motivó su apelativo de los "grandes cacaos" (Véase Tabla 3).

70 Según el texto original de Olavarriaga da un total de 4.546 .564 árboles de cacao. 


\section{Tabla 3}

Ubicación cantidad de árboles de cacao en la provincia de Venezuela 1720-1721

\begin{tabular}{|l|c|}
\hline \multicolumn{1}{|c|}{ Ubicación } & Árboles de cacao \\
\hline Jurisdicción de Caracas & 1.679 .800 \\
\hline Jurisdicción de San Sebastián & 165.000 \\
\hline jurisdicción de Valencia & 1.272 .900 \\
\hline Jurisdicción de Nirgua & 565.100 \\
\hline Jurisdicción de Barquisimeto & 807.764 \\
\hline Jurisdicción de Trujillo & 13.000 \\
\hline Jurisdicción de Carora & 6000 \\
\hline Jurisdicción de Coro & 37.000 \\
\hline Total & 4.546 .564 \\
\hline
\end{tabular}

Fuente: Pedro José de Olavarriaga, Instrucción General y particular del estado presente de la provincia de Venezuela en los años de 1720 y 1721 (Caracas: Academia Nacional de la Historia, 1965), 289.

Otra área de expansión del Teobroma se dirigió hacia el sur-oriente en la jurisdicción de La Grita, en la cual, de acuerdo con el encabezonamiento de tierras realizado en 1657, durante la visita de los oidores Modesto de Meller y Baños y Sotomayor, se describen propiedades cultivadas de cacao, que se extendían hacia el pie de monte del sur del Lago de Maracaibo, en Duragría, Onía, Mocotíes, Los Guaruríes, La Camaya, en el río de La Grita, Cariquena, Los Yeguienes y San Matheo ${ }^{71}$. Esa ruta de propagación de los cultivos de cacao fue extensiva hacia los afluentes del río Zulia, hasta San Faustino, Cúcuta y hacia el nororiente de la Nueva Granada desde donde se transportaba la producción en canoas hasta el lago de Maracaibo $^{72}$, junto con el azúcar y el melote, constituyéndose a finales del siglo XVIII en una de las regiones que exportaba más de 8.000 fanegas anuales a través del puerto de Maracaibo con destino a Veracruz ${ }^{73}$ (Véase Mapa 3).

71 Yariessa Lugo Marmignon, El becerro de La Grita, Joya de la Memoria (San Cristóbal-Venezuela: Editorial Lito-Lila, 1997), 49-54.

72 "Informe de las autoridades sobre el comercio en la laguna de Maracaibo", Mérida, 16 de febrero de 1740, AGEM, Empleados públicos de la colonia y bulas de santa cruzada, T. II, ff. 4r-5v.

73 Amado Antonio Guerrero M., et al., Los pueblos del cacao, orígenes de los asentamientos urbanos en el oriente colombiano (Bucaramanga: Universidad Industrial de Santander, Escuela de Historia y Fondo Mixto de Promoción de la Cultura y las Artes del Norte de Santander, 1998), 47; Armando Martínez Garnica, El régimen del resguardo en Santander (Bucaramanga: Gobernación de Santander, 1993), 70-73. 


\section{CONCLUSIONES}

De acuerdo con lo expuesto es indudable que el cacao criollo se halló en el sur del Lago de Maracaibo, donde era cultivado por los indígenas, específicamente en Maruma. Desde esa área, se expandió su cultivo a los valles colindantes debido a la creciente demanda que se tenía de las deliciosas nueces en México, por cuya razón se roturaron las tierras y se ensanchó la frontera agrícola, al mismo tiempo que se propagaba el Teobroma. De ese modo, los cultivos aborígenes iniciales fueron propagados por los hispanos quienes sembraron las arboledas de cacao en los diferentes valles de la planicie lacustre, como Chirurí, La Arenosa, Espíritu Santo, Bobures, Tucaní, Chama, Castro y Arapuey, conformando las ricas haciendas cuya producción se exportaba a Cartagena, Puerto Rico, Veracruz y Sevilla. Simultáneamente, el cultivo del Teobroma se difundió hacia Trujillo y desde allí a los valles centrales del litoral caraqueño. Con la misma fortaleza e intensidad avanzó hacia La Grita, San Cristóbal, Cúcuta y el nororiente de la Nueva Granada. Mediante ese proceso de crecimiento de la cultura del Teobroma se ofreció al mundo una de las especies más exquisitas de cacao que actualmente degusta la humanidad.

\section{BiblografíA}

\section{Fuentes primarias}

\section{Archivos}

Archivo General de Indias (Sevilla-España)

Escribanía de Cámara. Legajo 836-c.

Quito, 28, N. 55.

Patronato, 168, N 1, R. 1.

Santa Fe. Legajo 133.

Santo Domingo. Legajo 6.

Archivo General del Estado Mérida (Mérida-Venezuela)

Protocolos T. I al XL.

Mortuorias T. I al X.

Empleados públicos de la colonia y bulas de santa cruzada T. II.

Biblioteca Nacional Febres Cordero (Mérida-Venezuela)

Cabildo Mercedes de Tierra, Caja 12, Documento 1,

Colección Ciudades de Venezuela, R. 9. Vol. 2. 


\section{Impresas}

Cey, Galeotto. Viaje y descripción de las Indias (Estudio preliminar, notas e índices de José Rafael Lovera). Caracas: Fundación Banco Venezolano de Crédito, 1995.

“Corografía de la Gobernación de Venezuela y Nueva Andalucía, 1571 1574, por Juan López de Velazco”. En Relaciones Geográficas de Venezuela. Caracas: Colección Fuentes para la Historia Colonial de Venezuela. 70, Recopilación, estudio preliminar y notas de Antonio Arellano Moreno. Academia Nacional de la Historia, 1964, 95-110.

"Descripción de la ciudad de la Nueva Zamora, su término y Laguna de Maracaibo, hecha por Rodrigo de Argüelles y Gaspar de Párraga de orden del Gobernador don Juan de Pimentel". En Relaciones Geográficas de Venezuela. Caracas: Colección Fuentes para la Historia Colonial de Venezuela, 70, Recopilación, estudio preliminar y notas de Antonio Arellano Moreno, Academia Nacional de la Historia, 1964, 201-219.

"Descripción de Santiago de León, Gobernación de Venezuela, 1578 por Juan de Pimentel". En Relaciones Geográficas de Venezuela. Caracas: Colección Fuentes para la Historia Colonial de Venezuela, 70, Recopilación, estudio preliminar y notas de Antonio Arellano Moreno, Academia Nacional de la Historia, 1964, 111-140.

Olavarriaga, Pedro José de. Instrucción General y particular del estado presente de la provincia de Venezuela en los años de 1720 y 1721. Caracas: Academia Nacional de la Historia, 1965.

Pedro Simón (fray). Noticias historiales de Venezuela. Caracas: Colección Fuentes para la Historia Colonial de Venezuela, 67. Academia Nacional de la Historia, 1963, T. I-II.

"Relación Geográfica firmada por Diego de Villanueva y Gibaja en que se describe la Gobernación de Venezuela y provincia de Caracas, corregimientos de La Grita y Tunja y la Gobernación de los Mussos”. En Relaciones Geográficas de Venezuela. Caracas: Colección Fuentes para la Historia Colonial de Venezuela, 70, Recopilación, estudio preliminar y notas de Antonio Arellano Moreno, Academia Nacional de la Historia, 1964, 285-302.

98 Vázquez de Espinoza, Antonio. Compendio y descripción de las Indias Occidentales. Separata de la Revista Nacional de Cultura No. 68 (mayo-junio 1948). 


\section{Libros}

Arcila Farías, Eduardo. Economía colonial de Venezuela. Caracas: Italgráfica, 1973. T. I-II.

Borah, Woodrow. New Spain century of depression. Los Angeles: Berkeley, 1951.

Castillo Lara, Lucas Guillermo. San Sebastián de los Reyes. La ciudad trashumante. Caracas: Academia Nacional de la Historia, 1984, T. I.

Chessman, E.E. "Notes on nomeclatura, clasification and posible relationship of cacao populations". Trop. Agriculture (Trinidad) Vol. 21 No. 8, 144-159.

Febres Cordero, Tulio. "El chocolate y el chorote. Estudio histórico". En Archivo de Historia y Variedades. Caracas: Parra León Hermanos, 1930. T. I, 65-66.

Ganteaume, Juan. Chuao antes de la obra pía. Caracas: Editorial El Perro y la Rana, 2006.

Guerrero M., Amado Antonio et al. Los pueblos del cacao, orígenes de los asentamientos urbanos en el oriente colombiano. Bucaramanga: Universidad Industrial de Santander, Escuela de Historia y Fondo Mixto de Promoción de la Cultura y las Artes del Norte de Santander, 1998.

Israel, Jonathan D. Razas, clases sociales y vida política en el México Colonial 1610-1670. México: Fondo de Cultura Ecónomica, 1980.

Konetzke, Richard. América Latina II. La época colonial. México: Siglo XXI, 1977.

Lanaud, C., Lachenaud, Ph., Sounigo, O. "Comportement en croisement des haploïdes doublés de cacaoyers (Theobroma cacao)". Canadian Journal of Botany, 66, 1988, 1986-1992.

Lanaud C., "Nouvelles données sur la biologie du cacaoyer (Theobroma cacao L.): diversité des populations, système d'incompatibilité, haploïdes spontanés. Leurs conséquences pour l'amélioration génétique de cette espèce". Orsay: Université de Paris-Sud, 262 p. (Thèse de doctorat -- Amélioration des plantes, 1989).

Lanaud C., Motamayor J. C. \& Sounigo O. "Le cacaoyer". In Collection Repères Diversité génétique des plantes tropicales cultivées. P. Hamon et al., Eds. Cirad, 1999, 387. 
Lanaud, C., Nouvelle donnéssur le biologie du cacaoyer (Theobroma cacao L) diversité des populetions, system d'incompatibilité, haploides spontanés. Leurs consecuences pour l'amelioration genétique de cette specie. Doctorat détat. Paris: XI, 1991.

Lanaud, C., Riesterucci, A.M., Ngoran, J.A.K., Clement, D., Flament, M.H., Laurent, V. \& Falque M. "A genetic linkage map of Theobroma cacao L." Theoretical and Applied Genetics Vol. 91 No. 6-7, 1995, 987-993.

Laurent, V., Riesterucci, A. M. \& Lanaud C. "Variability for nuclear ribosomal genes within Theobroma cacao". Heredity 71, 1993a, 96-103. Laurent, V., Riesterucci, A. M. \& Lanaud C. "Chloroplast and mitochondrial DNA diversity in Theobroma cacao". Theoretical and Applied Genetics Vol. 87 No. 1-2, 1993b, 81-88.

Laurent, V., Riesterucci A. M. \& Lanaud C. "Genetic diversity in cocoa revealed by cDNA probes". Theoretical and Applied Genetics 88, 1994, 193-198.

Laviana Cueto, María Luisa. "Investigación e integración: La ruta del cacao en América Latina”. En Tierra Firme, Vol. XXV No. 100 (2007): 485-499.

Lugo Marmignon, Yariessa. El becerro de La Grita, Joya de la Memoria. San Cristóbal-Venezuela: Editorial Lito-Lila, 1997.

Martínez Garnica, Armando. El régimen del resguardo en Santander. Bucaramanga: Gobernación de Santander, 1993.

Miño Grijalva Manuel. El cacao Guayaquil en la Nueva España, 17741812 (Política imperial, mercado y consumo). México: El Colegio de México, 2013.

Motamayor, J. C. "Estudio de la variabilidad genética de los cacaoteros criollos de Venezuela Theobroma cacao L. mediante el uso de marcadores moleculares de tipo RFLP". (Tesis, Universidad Central de Venezuela, Facultad. Agronomía. Maracay, 1995).

Picón Febres, Gonzalo. Libro Raro. Mérida: Talleres Gráficos Universitarios, 1964.

Pittier, Henri. Manual de las plantas usuales de Venezuela y su suplemento. Caracas: Fundación Eugenio Mendoza, 1971.

Ramírez Méndez, Luis Alberto. "De la tentación al pecado de la comida del convento de Santa Clara de Mérida". En Ensayos Históricos. Anuario del Instituto de Estudios Hispanoamericanos No. 20 (2008): 41-56. 
Ramírez Méndez, Luis Alberto. La tierra prometida del sur del lago de Maracaibo y la villa y puerto de San Antonio de Gibraltar siglos XVI-XVII. Caracas: El Perro y la Rana, 2011, T. I-II.

Reyes, Humberto y Capriles de Reyes, Lilian. El cacao en Venezuela. Moderna tecnología para su cultivo. Caracas: Editado por Chocolates del Rey, 2000.

Riley, C. Michel. "El prototipo de la hacienda en el centro de México. Un caso en el siglo XVI". En Haciendas, latifundios y plantaciones en América Latina. Enrique Florescano (comp.). México: SIAP-CLAPSO, Siglo XXI, 1979, 19-71.

Samudio A., Edda O. Las haciendas del colegio San Francisco Xavier de la Compañía de Jesús en Mérida. 1628-1767. Caracas: Universidad de Los Andes, Arte, 1985.

Stanley, H. J. y Stein, Bárbara H. La herencia colonial de América Latina. México: Siglo XXI, 1975.

Tovar Pinzón, Hermes. Colombia. Imágenes de su diversidad (1492 a hoy). Bogotá: Grupo Editorial Educar, 2007.

\section{Digitales}

http:/ /www.gastronomiaycia.com/2008/07/31/cacao-con-3750-anosde-antiguedad/

http://www.analitica.com/va/arte/actualidad/8209705.asp Porcelana del Pedregal.

Sereno, María L., Paulo Albuquerque S. B., Roland, Veconvsky, Antonio, Figueira. "(Teobroma cacao L.) From Brazilian Amazon evaluated by microsatelitte markers". Conservacion genetics 7 (2006): 13-24. Disponible en: http://worldcocoafoundation.org/wp-content/files_mf/sereno2006geneticdiversity312kb.pdf

Para citar este artículo: Ramírez Méndez, Luis Alberto. "El cultivo del cacao venezolano a partir de Maruma", Historia Caribe Vol. X No. 27 (Julio-Diciembre 2015): 69-101. DOI: http://dx.doi.org/10.15648/ hc. 27.2015 .3 